\section{Development of the technology for obtaining new hydrogel materials based on acrylic monomers}

Nurabay N.D., Abutalip M. Rakhmetullayeva R.K., Mun G.A.*

Al-Farabi Kazakh National University, Almaty, Kazakhstan

*E-mail: grigoriy.mun@kaznu.kz
Smart water-soluble polymers and hydrogels are capable to reversibly react to insignificant changes of the medium properties $(\mathrm{pH}$, temperature, ionic strength, a presence of some substances, illumination, electric field). The reacting of a system is visible to the naked eye (the formation of a new phase in a homogeneous solution, or compression of the hydrogel). The properties of such polymers and hydrogels are considered. For the first time, the stimuli-responsive polymeric hydrogels based on $\mathrm{N}$-isopropylacrylamide (NIPAAM), 2-hydroxyethyl acrylate (HEA) and acrylic acid (AA) have been synthesized by free initiation of radical copolymerization. The purpose of the research is to obtain stimuli-responsive cross-linked terpolymers based on $\mathrm{N}$-isopropylacrylamide, 2-hydroxyethy acrylate and acrylic acid and study their physicochemical properties. The physicochemical methods such as scanning electron microscopy, differential scanning calorimetry, infrared spectroscopy, gravimetry, cathetometric and thermogravimetric analyses were used in this study. To determine the thermal and $\mathrm{pH}$ - sensitivity of the modified copolymer, the effect of temperature on the NIPAAMHEA-AA nets (in different pH media) was studied. They are characterized by a thermally induced collapse and a dependence on a medium $\mathrm{pH}$. The interaction of copolymers with drugs such as lincomycin and gentamicin was studied for using the new copolymers as a drug carrier. To study the antibacterial properties and the transportation of physiologically active substances of hydrogel, the elimination of specially prepared bacteria by hydrogels with various medicinal ingredients were conducted.

Keywords: 2-hydroxyethyl acrylate; $\mathrm{N}$-isopropylacrylamide; acrylic acid; hydrogen bond gentamicin; lincomycin; hydrophobic interaction.

\section{Разработка технологии получения новых гидрогелевых материалов на основе акриловых мономеров}

Нурабай Н.Д., Абуталип М. Рахметуллаева Р.К., Мун Г.А.*

Казахский национальный университет им. аль-Фараби, Алматы, Казахстан

*E-mail: grigoriy.mun@kaznu.kz

Умные водорастворимые полимеры и гидрогели способны обратимо реагировать на незначительные изменения свойств среды (pH, температура, ионная сила, присутствие определенных веществ, освещенность, электрическое поле), причем реакция системы легко видна невооруженным глазом (образование новой фазы в гомогенном до этого растворе, резкое набухание или сжатие гидрогеля). Свойства подобных полимеров и гидрогелей были рассмотрены в работе. Впервые были получены стимулчувствительные полимерные гидрогели на основе $N$-изопропилакриламида (НИПААМ), 2-гидроксиэтилакрилата (ГЭА) и акриловой кислоты (АК) методом вещественного инициирования радикальной сополимеризации. Целью данной работы является получение стимулчувствительных сшитых терполимеров на основе $N$-изопропилакриламида, 2-гидроксиэтилакрилата и акриловой кислоты, изучение их физикохимических свойств. В качестве основных физико-химических методов исследования в работе использованы: сканирующая электронная микроскопия, дифференциальная сканирующая калориметрия, ИК спектроскопия, гравиметрия, катетометрические, термогравиметрические анализы. Для определения термо- и рН- чувствительности модифицированного сополимера изучалось влияние температуры на сетки НИПААМ-ГЭА-АК (в разных средах рН). Было определено, что для них характерны термоиндуцированный коллапс и зависимость от pH среды. Исследовано их взаимодействие с лекарственными веществами, такими как линкомицин и гентамицин, для использования новых сополимеров в качестве носителя лекарственного средства. С целью исследования антибактериальной способности и транспортизации физиологически активных веществ гидрогеля, были проведены испытания для устранения специально подготовленных бактерий гидрогелями с различными лекарственными ингредиентами.

Ключевые слова: 2-гидроксиэтилакрилат; $N$-изопропилакриламид; акриловая кислота водородные связи; гентамицин; линкомицин; гидрофобные взаимодействие.

\section{Акрил мономерлері негізіндегі жаңа гидрогельді материалдарды алу технологиясын жасау}

Нұрабай Н.Д., әбутәліп М., Рахметуллаева Р.Қ., Мун Г.А.*

Әл-Фараби атындағы Қазақ ұлттық университеті, Алматы, Қазақстан *E-mail: grigoriy.mun@kaznu.kz
Суда еритін «ақылды» полимерлер мен гидрогельдердің ішінде ортаның аздаған өзгерістеріне (pH, температура, иондық күш, арнайы қосылған заттар, жарық, электр өрісі) жауап беретін гидрогелдерді айтамыз және жүйедегі өзгерістерді қалыпты жағдайда да байқауға болады (бастапқы гомогенді ерітіндіде жана фазаның түзілуі, кенеттен ісіну немесе гидрогельдің сығылуы). Жұмыста осындай полимер мен гидрогелдің қасиеттері қарастырылды. Заттық инициирленген радикалды сополимерлеу әдісімен, алғаш рет $N$-изо-пропилакриламид (НИПААМ), 2-гидроксиэтилакрилат (ГЭА) және акрил қышқылы (АҚ) негізіндегі стимулсезімтал полимерлі гидрогельдер алынды. Жұмыстың мақсать - N-изопропилакриламид, 2-гидроксиэтилакрилат және акрил қышқылы негізіндегі стимулсезімтал торлы терполимерлерді алу, олардың физика-химиялық қасиеттерін зерттеу. Жұмыста зерттеудің негізгі физика-химиялық әдістері ретінде сканерлеуші электронды микроскопия, дифференциалды сканерлеуші калориметр әдісі, иқспектроскопия, гравиметрия, катетометрлік, термогравиметриялық талдаулар қолданылды. Модифицирленген сополимердің термо- және рН-сезімталдығын анықтау мақсатында, алынған жаңа НИПААМ-ГЭА-АҚ торларына (әр түрлі рН ортада) температураның әсері зерттелген. Оларға термоиндуцирлік коллапстың тән екені және ортаның рН-на тәуелділіг анықталды. Олардың гентамицин және линкомицин сияқты дәрілік заттармен әрекеттесу зерттелді. Жұмыстың практикалық маңыздылығы, жаңа сополимерлерді дәрілік затть тасымалдаушы ретінде қолдану. Гельдердің физиологиялық белсенді заттарды тасымалдау және бактерияға қарсы қабілетін зерттеу мақсатында құрамында табиғаты әр түрлі дәрілік заты бар гидрогельдердің арнаулы дайындалған бактерияларды жою сынақтары жүргізілді.

Түйін сөздер: 2-гидроксиэтилакрилат; $N$-изопропилакриламид; акрил қышқылы; сутекті байланыс; гентамицин; линкомицин; гидрофобты әрекеттесулер. 


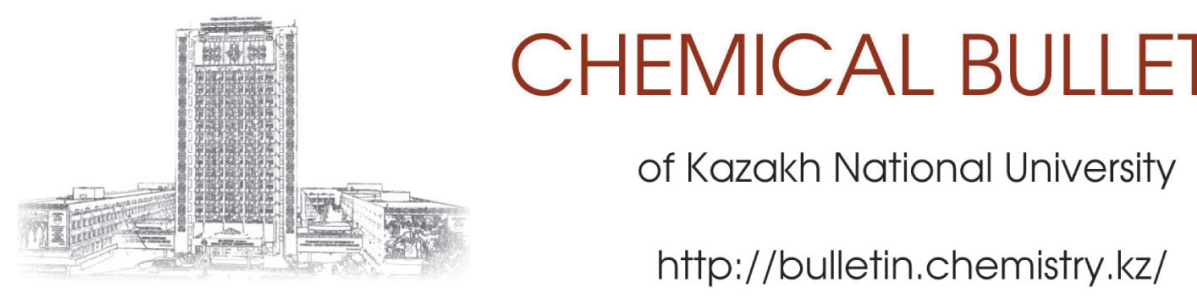

UDC 541.64

http://doi.org/10.15328/cb959

\title{
Development of the technology for obtaining new hydrogel materials based on acrylic monomers
}

\author{
Nurabay N.D., Abutalip M., Rakhmetullayeva R.K., Mun G.A.* \\ Al-Farabi Kazakh National University, Almaty, Kazakhstan \\ *E-mail: grigoriy.mun@kaznu.kz
}

\section{Introduction}

In recent years, so-called "smart materials" (smart or intelligent materials) attract much attention of researchers. Under this name, materials that can react to small changes in the external environment in a preprogrammed manner are combined [1]. Among the water-soluble polymers and hydrogels, "intelligent" systems can be named that react reversibly to small changes in the properties of the medium $(\mathrm{pH}$, temperature, ionic strength, the presence of certain substances, light, electric field), the response of the system being easily visible to the naked eye (the formation of a new phase in a solution homogenous before this, a sharp swelling or contraction of the hydrogel). Among synthetic polymers, the polymer systems based on $\mathrm{N}$-isopropylacrylamide (NIPAAM) having characterized by the lowest critical dissolution temperature (LCDT) in water are characterized by thermal sensitivity [2]. Homa- and copolymers of NIPAAM are readily prepared by radical polymerization in aqueous or organic solvents $[3,4]$.

Of great interest to researchers are stimuli-sensitive hydrogels because of their successful application in various fields, from biomedicine and pharmaceuticals to industrial applications [5].

Poly-NIPAAM is soluble in acetone, formamide, dioxane, tetrahydrofuran, lower alcohols, cold water; it forms a separate phase at a temperature of about $32^{\circ} \mathrm{C}$, and the LCDT is almost independent of the molecular weight (M) [4].The solubility of poly- $N$-isopropylacrylamide (PNIPAAM) below $32^{\circ} \mathrm{C}$ is due to the availability of hydrophilic functional groups ( $>\mathrm{NH}$ group), but the precipitation is higher than the temperature of the LCDT, indicating that the composition contains hydrophobic functional groups (isopropyl group) [6].

The relevance of the study is due to the fact that the copolymers obtained on the basis of NIPAAM-GEA-AA can be used as a promising material in the preparation of a system of a drug substance separating agent or a macromolecular therapeutic system as a depot.

Objects of study are triple stimuli-responsive copolymer based on $\mathrm{N}$-isopropylacrylamide (NIPAAM), 2-hydroxyethyl acrylate (HEA) and acrylic acid (AA).

The purpose of this work is to obtain the stimuli-responsive cross-linked terpolymers based on NIPAAM, HEA and AA and study of their physicochemical properties.

\section{Experiment}

Methods of investigation: IR spectroscopy (Satellite FTIR spectrophotometer, Mattson, USA) [7], free radical copolymerization [8], gravimetric measurements (ISO 9001 analytical scales, Sartorius, Germany), catethometric measurements ( cathetometer V-630, Russia), thermogravimetry (TGA/SDTA851e, METTLER TOLEDO, Switzerland), differential scanning calorimetry (NETZSCH DSC200 PC model, Perkin elmer, USA); scanning electron microscopy (Carl-Ziess SMT, Germany).

Crosslinked copolymers based on NIPAAM-GEA-AA were synthesized by the method of radical copolymerization at a temperature of $333 \mathrm{~K}$. Copolymerization was carried out in an ampoule made of molybdenum. For removing oxygen from the reaction mixture, which was in the ampoule for $20 \mathrm{~min}$, it was blown with argon gas. As an initiator, ammonium persulfate was used, and bis-acrylamide was used as the cross-linking agent. The resulting gels were washed with distilled water for 20 days.

Thermal analysis is a complex of methods for determining the temperatures at which processes occur, accompanied by the release of heat (for example, crystallization from a liquid) or its absorption (e.g., melting, thermal dissociation). Thermal analysis makes it possible to determine the temperatures of phase transitions. Heating or cooling the object, measure its 
temperature at small intervals; the measurement results are plotted graphically, plotting the time along the abscissa axis, and the temperature along the ordinate axis. The most common type of thermal analysis is differential thermal analysis (DTA)[9]. We used the method of thermal analysis, in which the change in the mass of the sample as a function of temperature is recorded. Thermogravimetric analysis was carried out using nitrogen gas at a stable atmospheric pressure at $30-900^{\circ} \mathrm{C}$ at the rate of $20^{\circ} \mathrm{C} / \mathrm{min}$.

Differential Scanning Calorimetry (DSC) is a method used to study what happens to polymers upon heating. This method studies what we call phase transitions of the polymer. Phase transitions are the changes that occur in the polymer when it is heated. One example of a phase transition is the melting of a crystalline polymer. Glassification is also a phase transition. The glass transition temperature was determined using the DSC method.

Scanning electron microscopy is a method for analyzing the surface structure of a solid microobject by means of an electron microscope, consisting in viewing a reflected "electronic image." Scanning electron microscopy allows us to investigate not only the properties of the sample surface, but also to visualize, as well as to obtain information about the properties of subsurface structures buried down to several microns [10].

The reaction of complex formation of copolymers with drug substances was studied using turbidimetric titration (UV spectrophotometer, Shimadzu UV/VIS-2401 PC, Japan) at the wavelength of $400 \mathrm{~nm}$. For this, the same concentrations of copolymer samples and aqueous solutions of medicinal substances were used.

The $\mathrm{pH}$ value of the solutions was determined on the lon Meter 3345 (Jenway LTD., UK) to normalize the $\mathrm{pH}$ value in the used solutions of $0.1 \mathrm{n} \mathrm{HCl}$ and $\mathrm{NaOH}$, as well as standard solution buffers.

In the course of the work, in order to study the properties of the thermal sensitivity of a polymeric network, polymers of a cylindrical shape with a uniform swelling, with a diameter of 5-7 $\mathrm{mm}$ and a height of 2-3 $\mathrm{mm}$, they are placed in a heated cell with water and kept at a given temperature range.

To determine the degree of swelling of the $\mathrm{pH}$ of the dependent hydrogel, the weight of the polymer was determined in the time interval. The degree of swelling of the hydrogel was calculated by this formula:

$$
\alpha=\frac{m-m_{0}}{m_{0}}
$$

where: $\alpha$ - the degree of swelling of the hydrogel; $m$ - the mass of the swollen gel; $m_{0}-$ the mass of dry gel.

In order to study the antibacterial ability and the transportation of physiologically active substances of hydrogel, tests were conducted to eliminate specially prepared bacteria with hydrogels with various medicinal ingredients.

The activity of the samples was determined by the degree of disadaptation of the growth rate of S. aureus IMB 3316 antiseptic inactivation of microorganisms according to the European standard after antiseptic incubation (European Standard EN 1040, 1997). Hydrogels and samples with medicinal substances (lincomycin and gentamicin) were taken as a tablet.

\section{Results and Discussion}

To determine the physicomechanical properties of a copolymer of the composition NIPAAM-GEA-AK, a thermogravimetric analysis method was carried out. In the composition of the copolymer, the greater number of units of acrylic acid, the more the intensity line changes. When the initial monomer mixture (IMM) of acrylic acid is $10 \%(1)$, then at a temperature of $337^{\circ} \mathrm{C}(87.95 \%)$ the copolymer loses its initial weight and completely decomposes.When the initial monomer of acrylic acid is $20 \%(2)$, then at a temperature of $341^{\circ} \mathrm{C}$ $(88.028 \%)$ the copolymer loses its initial weight and completely decomposes.When the initial monomer of acrylic acid is $30 \%$ (3), then at a temperature of $349^{\circ} \mathrm{C}(86.335 \%)$ the copolymer loses its initial weight and completely decomposes (Figure 1).

The DSC method was performed at a temperature of 30 $400^{\circ} \mathrm{C}$ and a rate of $20^{\circ} \mathrm{C} / \mathrm{min}$. If acrylic acid is $10 \%$ in the initial monomer, the glass transition temperature is $154.84^{\circ} \mathrm{C}(1)$. If the content of acrylic acid is $20 \%, \mathrm{Tg}=180.14^{\circ} \mathrm{C}$ (2). And with $30 \%$ acrylic acid, $\mathrm{Tg}=170.50^{\circ} \mathrm{C}(3)$.

This means that with the increase in the percentage of acrylic acid, this copolymer is enriched with them (Figure 2).

The morphology of the obtained copolymer was studied by scanning electron microscopy. The surface layer of the polymer is shown in the Figure 3. The photo is given at 20 and $100 \mu \mathrm{m}$ resolutions. When the mole fraction of acrylic acid in the initial monomeric mixture is $10 \%$ (Figure 3 ), then on the surface layer of the copolymer there are many pores, and they are bulky. This shows that the resulting copolymer is prone to swelling which confirms the above findings.

It is shown that in the acidic medium ( $\mathrm{pH} 4$ ) (Figure 4a), when the polymer is swollen in water, depending on the percentage of acrylic acid, the compression amplitude can be different. In the composition of IMM, if the volume of acrylic acid is $10 \%$, then the compression amplitude decreases 6 times; at $20 \%$, the compression amplitude decreases 9 times; at 30\% the lowest compression amplitude was observed. When the volume of acrylic acid increases in a three-component composition, the distance of the cross-linking sites is very low, and this is due to the formation of a very dense cellular structure (Figure 4a).

It was found that at the lower molecular volume of acrylic acid $(10 \%)$, the lower number of dissociated groups will be available. At $30 \%$, it was determined that the carboxyl groups in the densest grid were only absorbed at the primary temperature (Fig. $4 \mathrm{~b}, \mathrm{pH}=9$, curve 3 ) in the initial temperature range (20$30^{\circ} \mathrm{C}$ ) because of the ionization capacity of the carboxyl groups. And $20 \%$ is explained by the advantage of electrostatic discharge (Fig. 4b, $\mathrm{pH}=9$, curve 2).

To use the ternary system as the carrier of the drug substance, the interaction of the ternary system with drug substanc- 

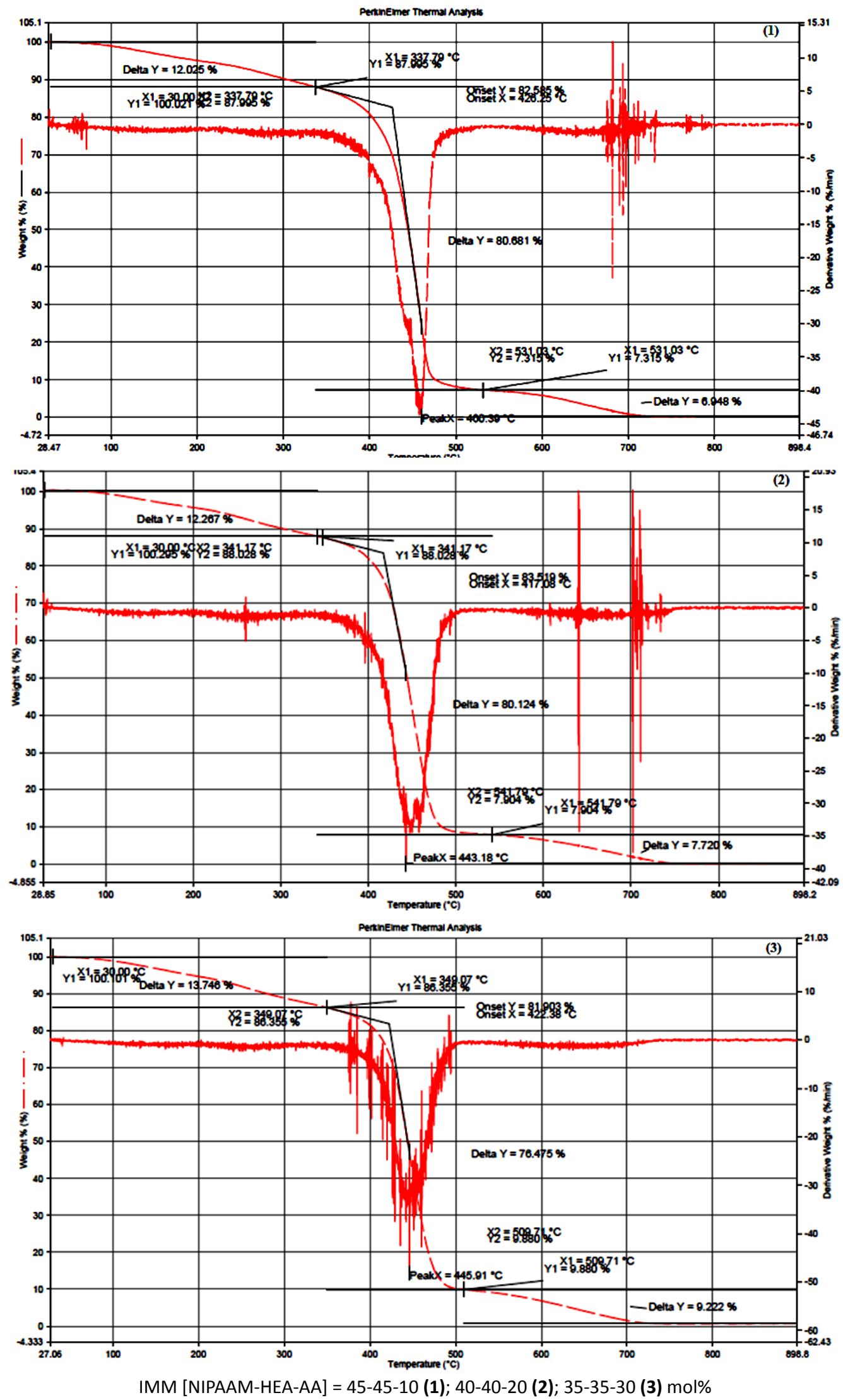

Figure 1 - Results of the thermogravimetric analysis of the copolymer NIPAAM-HEA-AA 

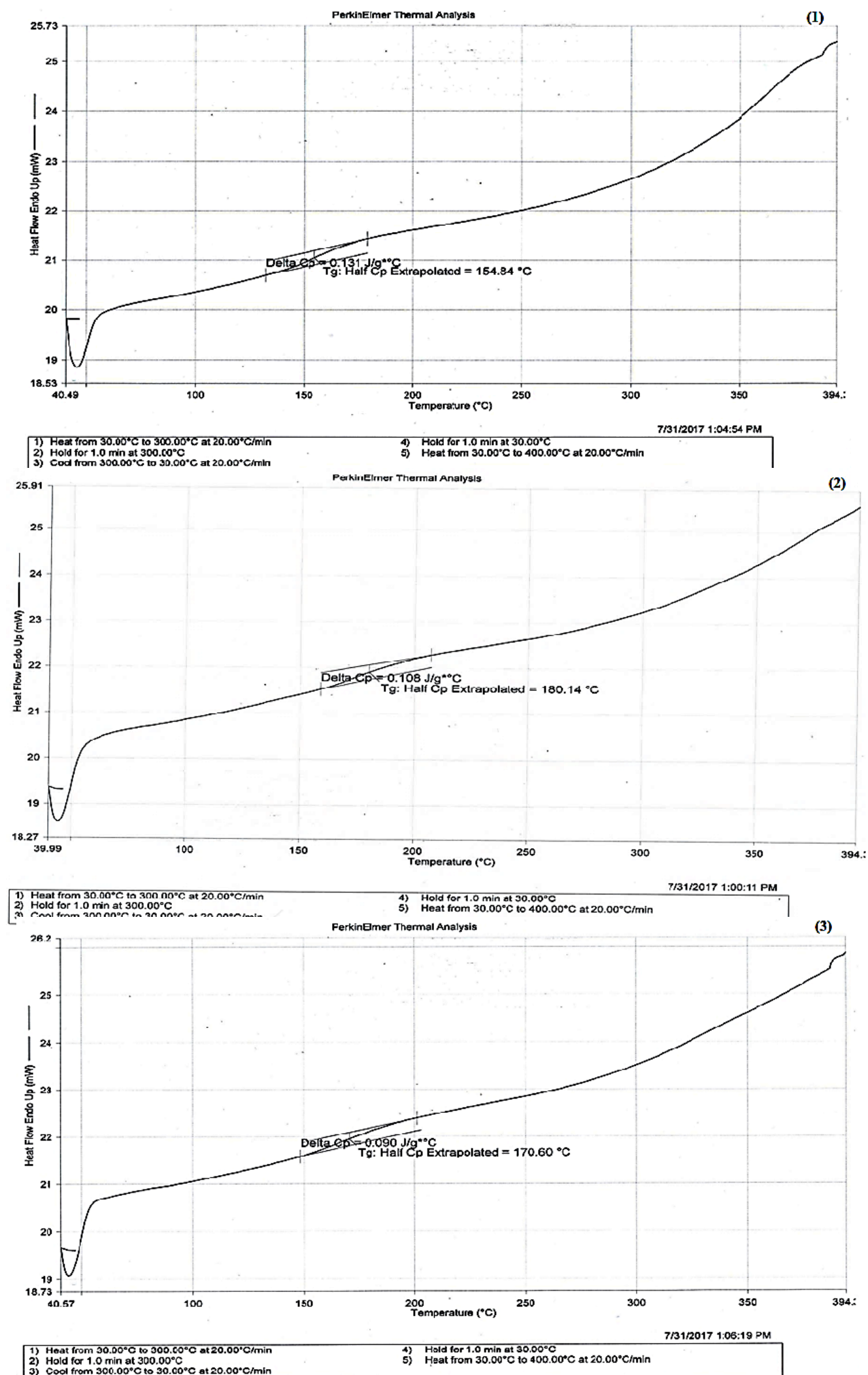

IMM [NIPAAM-HEA-AA] = 45-45-10 (1); 40-40-20 (2); 35-35-30 (3) mol\%

Figure $\mathbf{2}$ - Results of the differential scanning calorimetry analysis of the copolymer NIPAAM-HEA-AA 

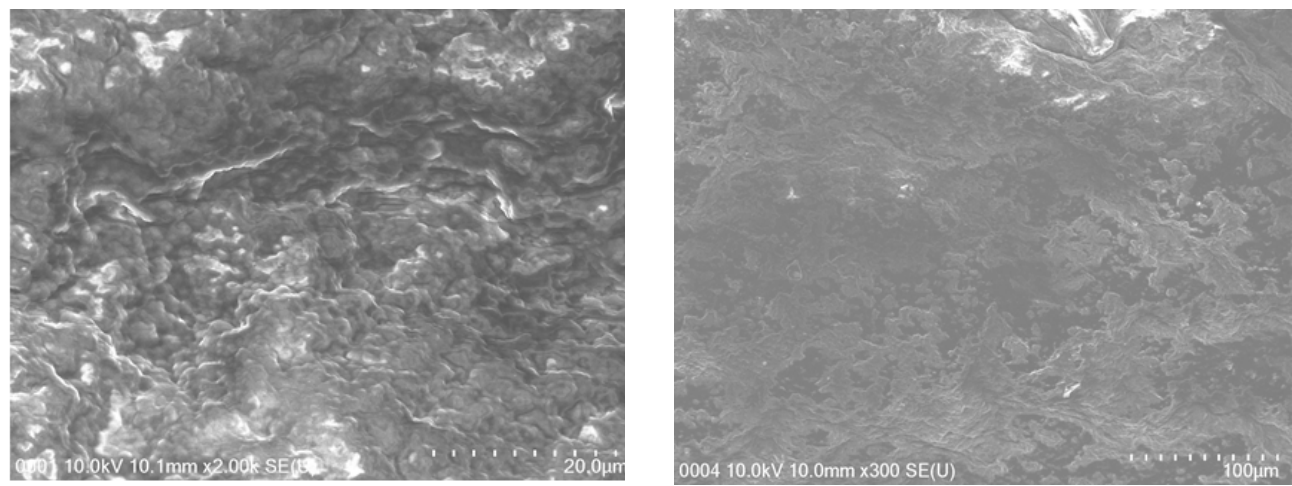

IMM [NIPAAM-HEA-AA] = 45-45-10 mol\%

Figure 3 - Surface layer of a copolymer by scanning electron microscopy
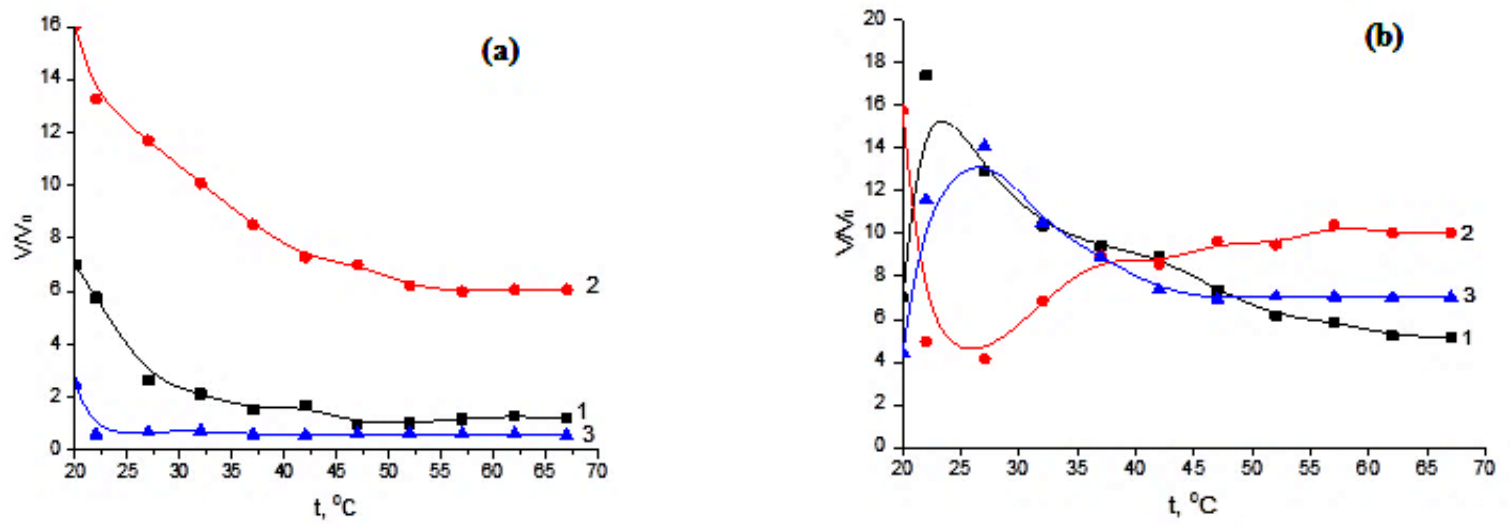

IMM [NIPAAM-HEA-AA] = 45-45-10(1); 40-40-20 (2); 35-35-30 (3) mol\%; pH=4(a); pH=9 (b)

Figure 4 -The change in the volume of the NIPAAM-HEA-AA hydrogel as a function of temperature

es was investigated. As drugs lincomycin and gentamicin were taken. In the study, all polymer samples swell in lincomycin additionally, while sodium chloride and gentamicin weakly swelled (Figure 5). This is due to the ionization of the carboxyl groups in the polymer due to the additional swelling of the lattice (Figure 5 , curve 2 ) and a decrease in the swelling of the other two due to the decrease in the polyelectrolytic effect and the formation of a complex of polyelectrolytes.

IR spectra of a triple system and samples with medicinal substances were collected. In the composition of the copolymer, it was found out that the intensity of the band changes with an increase in the size of the chain of acrylic acid. There are no double bonds here. As can be seen from the obtained values, it is proven that in the spectrum of new samples of the band 1660$1680 \mathrm{~cm}^{-1}$ corresponds to the amide group, the bands 3150 $3200 \mathrm{~cm}^{-1}$ per NH-group, the band $1720-1725 \mathrm{~cm}^{-1}$ corresponds to the group - $\mathrm{COOH}$ acrylic acid (Figure 6), bands corresponding to lincomycin $2879 \mathrm{~cm}^{-1}$ (Figure 7) and gentamycin 2424-2357 $\mathrm{cm}^{-1}$ were detected (Figure 8 ). To compare the results, the IR spectrum table is shown (Table 3).

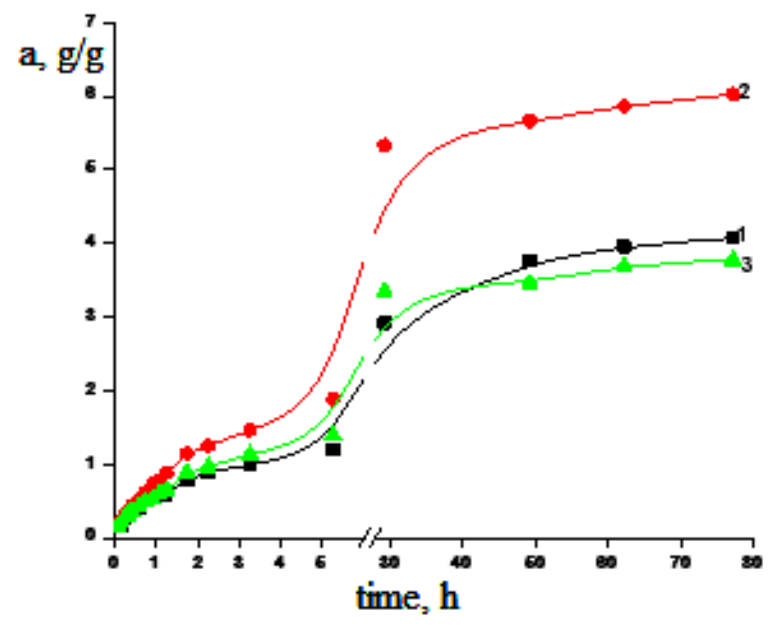

IMM [NIPAAM-HEA-AA] = 45-45-10 mol\%; $\mathrm{NaCl}$ (1) 0.9\%; lincomycin (2); gentamicin (3) 0.05 mol\%

Figure $\mathbf{5}$ - Kinetics of swelling of hydrogel NIPAAM-HEA-AA in different media 


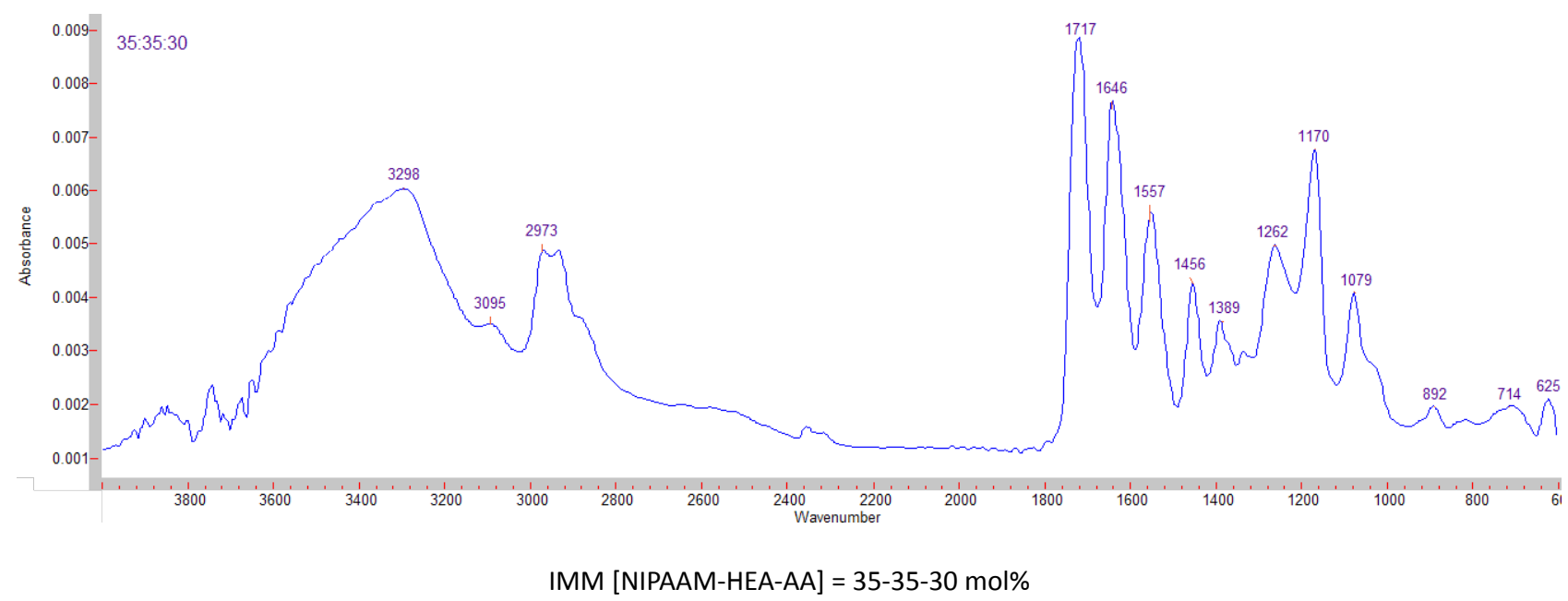

Figure 6 - IR spectrum of hydrogel NIPAAM-HEA-AA

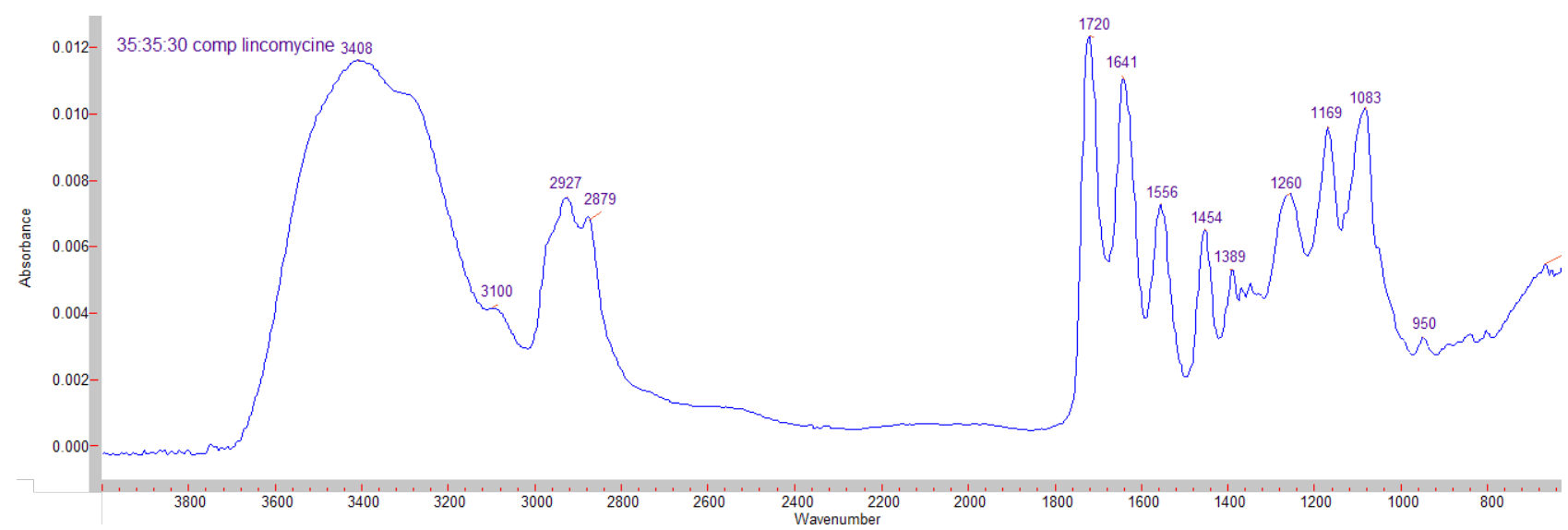

IMM [NIPAAM-HEA-AA] = 35-35-30 mol\%; comp. lincomycin

Figure 7 - IR spectrum of hydrogel NIPAAM-HEA-AAwith medicinal substances

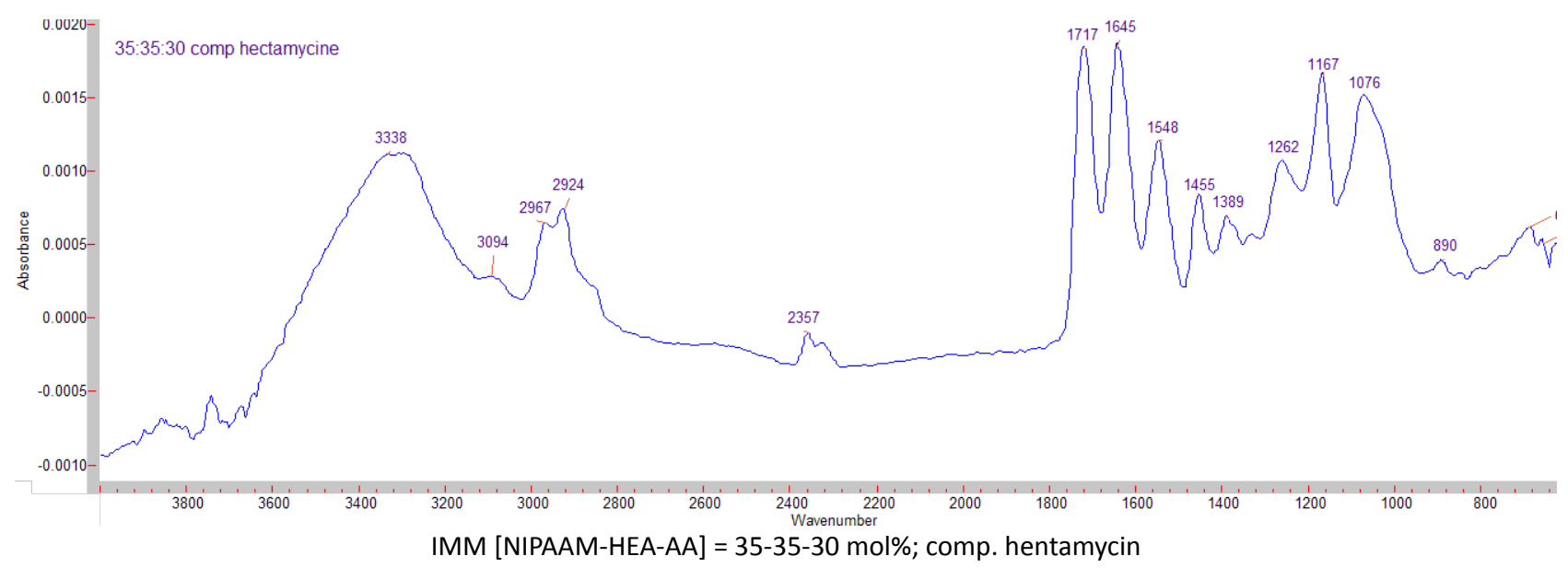

Figure 8-IR spectrum of hydrogel NIPAAM-HEA-AAwith medicinal substances 
Hydrogels with a monomeric $10 \%$ bond are active, and the bactericidal zone reached $27 \mathrm{~mm}$ (Figure 9). It has been found that hydrogels that have been combined with lincomycin and gentamicin solutions exhibit specific antimicrobial activity. It was found that hydrogels with lincomycin had a higher activity than with gentamycin, which means that the hydrogel tolerates lincomycin better than gentamicin (Table 4).

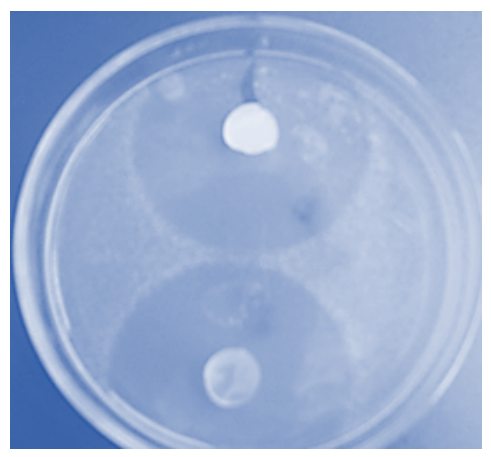

IMM [NIPAAM-HEA-AA]=45-45-10 (№ 1); 40-40-20 (№ 2)mol-\%; Growth of the fungus S. aureus IMB 3316(gel samples № 1-2 top to bottom)

Figure 9 - The microbial effect with gentamycin on the hydrogel NIPAAM-HEA-AA

Table 3 - Comparative table of IR spectra

\begin{tabular}{|c|c|c|}
\hline Designation & $\begin{array}{l}\text { Structural } \\
\text { fragments }\end{array}$ & Wave - number $\mathrm{cm}^{-1}$ \\
\hline \multirow{6}{*}{$\begin{array}{l}\text { IMM [NIPAAM-HEA-AA] } \\
=35-35-30 \mathrm{~mol} \%\end{array}$} & $-\mathrm{OH}$ & $3500-3298$ \\
\hline & ${ }^{1} \mathrm{NH}-$ & $3150-3200$ \\
\hline & $-\mathrm{C}-\mathrm{H}$ & $3095-2900$ \\
\hline & $-\mathrm{NH}-$ & \\
\hline & $-\mathrm{COOH}$ & $1717-1725$ \\
\hline & $-\mathrm{CO}-\mathrm{NH} 2$ & $1646-1680$ \\
\hline \multirow{7}{*}{$\begin{array}{l}\text { IMM [NIPAAM-HEA-AA] } \\
=35-35-30 \text { mol\%; comp. } \\
\text { hentamycin }\end{array}$} & $-\mathrm{OH}$ & $3500-3338$ \\
\hline & ${ }^{1} \mathrm{NH}-$ & $3150-3200$ \\
\hline & $-\mathrm{C}-\mathrm{H}$ & $3094-2900$ \\
\hline & $-\mathrm{NH}-$ & \\
\hline & $-\mathrm{COOH}$ & $1717-1725$ \\
\hline & $-\mathrm{CO}-\mathrm{NH} 2$ & $1645-1680$ \\
\hline & gentamicin lines & $2424-2357$ \\
\hline \multirow{7}{*}{$\begin{array}{l}\text { IMM [NIPAAM-HEA-AA] } \\
=35-35-30 \text { mol\%; comp. } \\
\text { lincomycin }\end{array}$} & $-\mathrm{OH}$ & $3408-3300$ \\
\hline & ${ }^{1} \mathrm{NH}-$ & $3100-3200$ \\
\hline & $-\mathrm{C}-\mathrm{H}$ & $3100-2927$ \\
\hline & $-\mathrm{NH}-$ & \\
\hline & $-\mathrm{COOH}$ & $1720-1725$ \\
\hline & $-\mathrm{CO}-\mathrm{NH} 2$ & $1641-1680$ \\
\hline & lincomycin lines & 2879 \\
\hline
\end{tabular}

Table 4 - Antibacterial ability of hydrogels containing medicinal substances

\begin{tabular}{|c|c|c|c|}
\hline \multirow[t]{2}{*}{ № } & \multirow{2}{*}{$\begin{array}{l}\text { IMM } \\
\text { [NIPAAM- } \\
\text { HEA-AA] } \\
\text { mol\% }\end{array}$} & \multirow[t]{2}{*}{$\begin{array}{l}\text { The amount of } \\
\text { drug included in } \\
\text { the hydrogel, } \%\end{array}$} & $\begin{array}{l}\text { The diameter of the growth } \\
\text { zone of the test organism } \\
\text { (control sample),mm }\end{array}$ \\
\hline & & & $\begin{array}{c}\text { Staphylococcus aureus IMB } \\
3316\end{array}$ \\
\hline 1 & $45-45-10$ & gentamicin, 10 & 52 \\
\hline 2 & $40-40-20$ & gentamicin, 10 & 52 \\
\hline 3 & $35-35-30$ & gentamicin, 10 & 55 \\
\hline 4 & $45-45-10$ & gentamicin, 20 & 55 \\
\hline 5 & $40-40-20$ & gentamicin, 20 & 53 \\
\hline 6 & $35-35-30$ & gentamicin, 20 & 53 \\
\hline 7 & $45-45-10$ & lincomycin, 15 & $\begin{array}{l}\text { Growth completely } \\
\text { eliminated }\end{array}$ \\
\hline 8 & $40-40-20$ & lincomycin, 15 & $\begin{array}{c}\text { Growth completely } \\
\text { eliminated }\end{array}$ \\
\hline 9 & $35-35-30$ & lincomycin, 15 & $\begin{array}{c}\text { Growth completely } \\
\text { eliminated }\end{array}$ \\
\hline 10 & $45-45-10$ & lincomycin, 30 & $\begin{array}{c}\text { Growth completely } \\
\text { eliminated }\end{array}$ \\
\hline 11 & $40-40-20$ & lincomycin, 30 & $\begin{array}{c}\text { Growth completely } \\
\text { eliminated }\end{array}$ \\
\hline 12 & $35-35-30$ & lincomycin, 30 & $\begin{array}{c}\text { Growth completely } \\
\text { eliminated }\end{array}$ \\
\hline 13 & $45-45-10$ & distilled water & 27 \\
\hline 14 & $40-40-20$ & distilled water & 0 \\
\hline 15 & $35-35-30$ & distilled water & 0 \\
\hline
\end{tabular}

\section{Conclusion}

For the first time, stimulus-sensitive polymers hydrogels based on $\mathrm{N}$-isopropylacrylamide (NIPAAM), 2-hydroxyethyl acrylate (HEA) and acrylic acid (AA) have been synthesized by free radical copolymerization.

To determine the physicomechanical properties of a copolymer of the composition NIPAAM-HEA-AK, a thermogravimetric analysis method was used. The morphology of the obtained copolymer was studied by scanning electron microscopy.

To determine the thermo- and pH-sensitivity of the modified copolymer, the effect of temperature on the net of hydrogels (in different $\mathrm{pH}$ media) of NPAAM-HEA-A was investigated. New polymer hydrogels are characterized by thermally induced collapse and it has been found that it depends on the $\mathrm{pH}$ of the medium.

The use of the triple system as a carrier of a drug substance, its interaction with drugs has been studied. The study found that all samples of water-soluble polymers additionally swell in lincomycin, compared with sodium chloride and gentamicin. IR spectra of a triple system and samples with medicinal substances were carried out. In the composition of the copolymer, it is found 
that, with an increase in the size of the chain of acrylic acid, the intensity of the band changes.

The activity of drug-immobilized hydrogels was determined by the degree of slowing of growth of $S$. aureus 3316 fungi. It has been found that hydrogels that have been combined with lincomycin and gentamicin solutions exhibit specific antimicrobial activity. It was found that hydrogels with lincomycin had a higher activity than with gentamicin, which means that the hydrogel tolerates lincomycin better than gentamicin.

\section{Acknowledgments}

This study was supported by a grant from the Ministry of Education and Science of the Republic of Kazakhstan 0201/ PCF-14 "Creation of new hydrophilic polymer materials and implementation of its practical applications based on methods of molecular programming in medicine, cosmetology, agriculture".

The authors express their gratitude to the Institute of Microbiology and Virology (Almaty, Kazakhstan), for determining the antibacterial ability and transporting physiologically active substances.

\section{References (GOST)}

1 Gisser K.R.C., Geselbracht M.J., Capellari A., Hunsberger L., Ellis A.B., Perepezko J., Lisensky G.C. Nickel-Titanium Memory Metal: A "smart" material exhibiting a solid-state phase change and superelasticity // Journal of Chemical Education. - 1994. - Vol. 71. - P. 334-340.

2 Galayev I.Yu. Smart' polymers in biotechnology and medicine // Russian Chemical Reviews. - 1995. - Vol. 64. - P. $471-489$.

3 Fujishige A., Kubota K., Ando I. Phase transition of aqueous solutions of poly(Nisopropylacrylamide) and poly(Nisopropylmethacrylamide) // Journal of Physical Chemistry. -1989. - Vol. 93. - P. 3311-3313.

4 Kubota K., Fujishige S., Ando I. Solution properties of poly(N-isopropyl-acrylamide) in water // Polymer Journal. - 1990. - Vol. 22. - P. 15-20.

5 Byrne M.E., Park K., Peppas N.A. Molecular imprinting within hydrogels // Advanced Drug Delivery Reviews. - 2002. - Vol. 54. - P. 149-161.

6 Safrany A. Synthesis and characterization of superclean thermo-reversible copolymer hydrogels // Radiation Physics and Chemistry. - 1999. - Vol. 55. - P. 121-126.

7 Тарасевич Б.Н. ИК-спектры основных классов органических соединений. Справочные материалы. - М.: Изд-во МГУ, 2012. - C. 4-29.

8 Nakan U., Rakhmetullayeva R.K., Mun G.A., Shaihutdinov E.M., Toktabayeva A.K. Synthesis and physico-chemical properties of copolymers based on $\mathrm{N}$-isopropyl acrylamide and 2-hydroxyethylacrylate // Proc. USM - KazNU Conf. 'Challenges of teaching \& chemistry research in institutions of higher learning'. - Penang, 2012. - P. 30.

9 Кизбаев И., Курманбекова А.К., Накан У. Новые стимулчувствительные сополимеры на основе N-изопропилакриламида // Матер. межд. конф. студентов и молодых ученых «Фараби Әлемі». - Алматы, 2014. - С. 107.

10 Ясников И.С., Нагорнов Ю.С., Горбачев И.В., Микеев Р.Р., Садовников П.С., Шубчинская Н.Ю., Аминаров А.В. Сканирующая электронная микроскопия как метод изучения микроскопических объектов электролитического происхождения // Фундаментальные исследования. - 2013. - № 1. - С. 758-764.

\section{References}

1 Gisser KRC, Geselbracht MJ, Capellari A, Hunsberger L, Ellis AB, Perepezko J, Lisensky GC (1994) J Chem Educ 71:334-340. https:// doi.org/10.1021/ed071p334

2 Galayev IYu (1995) Russ Chem Rev 64:471-489. https://doi.org/10.1070/RC1995v064n05ABEH000161

3 Fujishige A, Kubota K, Ando I (1989) J Phys Chem-US 93:3311-3313. https://doi.org/10.1021/j100345a085

4 Kubota K, Fujishige S, Ando I (1990) Polym J 22:15-20. https://doi.org/10.1295/polymj.22.15

5 Byrne ME, Park K, Peppas NA (2002) Adv Drug Deliver Rev 54:149-161. https://doi.org/10.1016/S0169-409X(01)00246-0

6 Safrany A (1999) Radiat Phys Chem 55:121-126.

7 Tarasevich BN (2012) IR spectra of the main classes of organic compounds. Reference materials [IK-spektry osnovnykh klassov organicheskikh soyedineniy. Spravochnyye materialy]. MGU, Moscow, Russia. P.4-29. (In Russian)

8 Nakan U, Rakhmetullayeva RK, Mun GA, Shaihutdinov EM, Toktabayeva AK (2012) Synthesis and physico-chemical properties of copolymers based on N-isopropyl acrylamide and 2-hydroxyethylacrylate. Proceedings of USM - KazNU Conference on Challenges of teaching \& chemistry research in institutions of higher learning, Penang, Malaysia. P.30.

9 Kizbayev I, Kurmanbekova AK, Nakan U (2014) New stimuli-sensitive copolymers based on N-isopropylacrylamide [Novye stimulchuvstvitel'nye sopolimery na osnove $\mathrm{N}$-izopropil-akrilamida]. Abstracts of the International conference of students and young scientists "Farabi Alemi", Almaty, Kazakhstan. P.107. (In Russian) 
10 Yasnikov IS, Nagornov YuS, Gorbachev IV, Mikeyev RR, Sadovnikov PS, Shubchinskaya NYu, Aminarov AV (2013) Fundamental research [Fundamental'nye issledovaniya] 1:758-764. (In Russian) 